\title{
JAFSCD
}

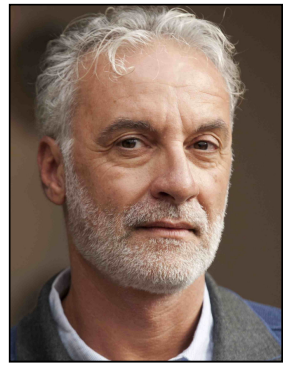

GLobal VieWS OF Local Food SyStems Reflections on the growing worldwide local food movement RAMI ZURAYK

\section{The agrarian limits of the food movement}

Submitted June 19, 2014 / Published online June 25, 2014

Citation: Zurayk, R. (2014). The agrarian limits of the food movement. Journal of Agriculture, Food Systems, and Community Development, 4(3), 19-22 . http://dx.doi.org/10.5304/jafscd.2014.043.018

Copyright (C) 2014 by New Leaf Associates, Inc.

Good was on the cover of the May 2014 issue of National Geographic magazine. Inside the glossy monthly's international edition, an attractively illustrated article entitled "A Five-Step Plan to Feed the World" by Jonathan Foley ran alongside a fullpage commercial by giant multinational company Syngenta, famous for its sale of seeds and agrochemicals and for its biotechnology and genomic research. The advertisement depicted an African woman farmer in the middle of a (GMO?) corn field with the caption: "She can feed a hungry world. We are going to help her do it." Here was a poignant and graphic representation of the discourse of the Second Green Revolution (SGR):

Rami Zurayk is professor at the Faculty of Agricultural and Food Sciences at the American University of Beirut, Lebanon. He studied at the American University of Beirut and at Oxford University, UK. His research addresses issues at the nexus of food, landscapes, and livelihoods. $\mathrm{He}$ is an active member of Lebanese civil society and a founder of Slow Food Beirut. He can be contacted at ramizurayk@gmail.com. the corporate world claiming to be reaching out to help its historic victims, the smallholders in the Global South.

Indeed, the Second Green Revolution, which aims to bring Africa into the realm of the industrial food producing nations, is not happening in the same way as its predecessor. This time, transnational corporations (TNCs) have joined forces with academic research centers and with big philanthropy to bring to Africa the latest in industrial capitalist farming, including high-yielding varieties and the accompanying technological package (see for example Rockefeller Foundation, 2006) for which they hold intellectual property rights. The interests of the Neoliberal Triad (TNCs-big philanthropy-academia) have become so intertwined in terms of funding, research and development, epistemic dominance, corporate social responsibility, and tax evasion that it now acts like a single organism - a hydra of sorts. For the purpose of penetrating the African continent, where lands and resources are still plentiful, the Triad is harnessing all its capabilities. These include 
the projection of a positive media image.

The deleterious effects of the First Green Revolution include widespread social and ecological tragedies, the shockwaves of which can still be felt. For instance, it is widely believed that the First Green Revolution induced a suicide epidemic among Indian farmers. Although the voices of capital have attempted to blur the discourse with glib assertions (see for example The Economist, 2014), the evidence from meta studies as presented in a recent Lancet article by Patel et al. (2014) is compelling: suicide rates are highest among smallholders unable to eke out a living in a world dominated by cash cropping and global markets. The death toll reached 187,000 deaths in 2010 alone (Patel et al., 2014). Indian philosopher and physicist Vandana Shiva has laid the blame directly on TNCs, and specifically on GMO giant Monsanto (Shiva, 2014).

Avoiding an African repeat of the Indian disaster will require more than good images made in bad faith. Beyond Syngenta's advertising looms the specter of an agrarian disaster associated with the demise of hundred of millions of rural livelihoods. The situation has been concisely presented by economist Samir Amin in a timely article on the Agrarian Question in the South (2012), whose central argument I summarize below using some of Amin's words:

There exists in today's world two systems of food production, one based on capitalist farming (rich family farms and agribusinesses), located mostly in North American, Europe, the southern cone of Latin America, and Australia. It involves a few million farmers who are not peasants and whose labor displays very high productivity — between 1,000 and 2,000 tons cereal equivalents (CE) per person. The other group is located in the countries of the Global South. It is mainly composed of peasants who have much lower labor productivity: $0.1-0.5$ tons CE for those who benefited from the Green Revolution and 0.01 tons CE for those who didn't. Their number is 3 billion people. As productivity gains are brought into the agrarian societies of the Global South, billions of farmers must be reduced to millions who will benefit from these advances. What happens to the others? The surplus labor that is created is far beyond the absorption capacity of national economies. Thus the advance of global capital into the agrarian South is bound to create an agrarian question that can only be resolved by a human and environmental genocide.

This is a rather disquieting assessment that places the Indian farmers' suicides into its real context.

To my mind, this is today the most crucial issue facing humanity. It has now become evident that most of the crises shaking the South, including ecological crises, can be traced to agrarian collapses. My recent work on the Arab uprisings shows that the demise of rural livelihoods and the inability of rent-based economies to absorb surplus labor were a main driver of the recent waves of violent revolutions and revolts (Zurayk, 2014).

The failings of the Green Revolution were made public chiefly through the grassroots efforts of organized civil society concerned with food and farming issues known as "the food movement." The success of the movement's grassroots campaigns in exposing the nefarious impacts of the First Green Revolution has prompted the Triad to borrow from the vocabulary of the food movement for its African project. Liveliboods, smallholders, localism, cooperatives, organic, and fair trade are terms that have become part of the corporate social responsibility drive that has bloomed in the past decade. Concurrently, the world of nongovernmental organizations (NGOs) has dug into the corporate book and appropriated new practices such as results-based management, professionalization, efficiency, cost-benefit, return on investment, and hierarchism. This has blurred the lines to such an extent that it has become difficult to distinguish between yesterday's foes - who now meet regularly in roundtables convened by the United 
Nations. A classic example is in the endless rounds of negotiations around the voluntary guidelines for land tenure convened by the FAO, which bring together civil society representatives from the South and the North along with official representatives of states, who often double up as corporate agents. No wonder the meetings lead nowhere. ${ }^{1}$

Confronted with today's disturbing agrarian reality and enriched by its experience of the first Green Revolution, can the food movement do anything to steer the agrarian world in the South away from its collision course? To properly address this issue, one first needs to understand the limits of action of the food movement. We chiefly need to remember that it is in fact a loose assemblage of international, national, and local movements that share often illdefined values. Chief among these is the belief that the world would be a better place if it adopted "alternative food systems." These food systems would foster food security and environmental conservation, as well as democracy and community integrity. This creates sufficient political space to include organizations as disparate as local farmers' markets and the Movement de San Terra. Selfdeclared members of the food movement do not need to agree on all the central tenets. More importantly, challenging the neoliberal project is not a requirement.

In a recent thought-provoking article, Alkon (2013) addressed the issue of the neoliberal ramifications of the food movement. The author presents a very useful typology of food movement organizations and identifies four distinct discourses: local and organic food, community food security, local food systems, and food sovereignty. Alkon argues convincingly that only the food sovereignty

\footnotetext{
${ }^{1}$ In the interest of full disclosure, I have participated in a number of such meetings as a civil society representative.
}

movement directly challenges neoliberalism, while activism in the other three discourses in effect relies on the dynamics of the market and on commodity relations ("the consumers voting with their forks"). Focusing specifically on fair trade, Goodman (2004) notes that while it provides the reflexive Northern consumer with a moral alternative to conventional trade, it fails to truly challenge the neoliberal ethos. Moreover, he adds that the adoption by giant corporations, such as Starbucks, of fair trade as part of their procurement and marketing campaigns poses seemingly unsolvable dilemmas to food justice activists who are now lost between the urge to boycott corporate coffee and that of supporting small, ecological coffee producers.

This cursory assessment of the situation may seem bleak. Seen from the South, it looks unfortunately far too realistic.

Many among us are bracing ourselves for the neoliberal cyclone that will continue to devastate land and people. The seemingly unstoppable land grabs, now euphemistically termed "overseas foreign investments," are only the tip of the iceberg. And while we believe that a just solution for the agrarians of the South can only be born out of global solidarity, we also know that it will not come in the shape of a tall organic shade-grown fair-trade cappuccino.

\section{References}

Alkon, A. H. (2013, September). Food justice, food sovereignty and the challenge of neoliberalism. Paper presented at the Food Sovereignty: A Critical Dialogue International Conference, Yale University, New Haven, Connecticut. Retrieved from http://www.yale.edu/agrarianstudies/foodsovereig nty/pprs/38_Alkon_2013.pdf

Amin, S. (2012). Contemporary imperialism and the agrarian question. Agrarian South: Journal of Political Economy, 1(1), 11-26. http://dx.doi.org/10.1177/227797601200100102 
Economist, The. (2014, March 13). GM Genocide? [Web log post]. Retrieved from http://www.economist.com/blogs/feastandfamine 2014/03/gm-crops-indian-farmers-and-suicide

Goodman, M. K. (2004). Reading fair trade: Political ecological imaginary and the moral economy of fair trade foods. Political Geography, 23(7), 891-915. http://dx.doi.org/10.1016/j.polgeo.2004.05.013

Patel, V., Ramasundarahettige, C., Vijayakumar, L., Thakur, J S, Gajalakshmi, V., Gururaj, G., Suraweera, W., \& Jha, P., for the Million Death Study Collaborators. (2012). Suicide mortality in India: A nationally representative survey. Lancet, 379, 2343-2351. Retrieved from http://press.thelancet.com/indiasuicide.pdf
Rockefeller Foundation. (2006). Africa's turn: A new Green Revolution for the 21st century. New York: Author. Retrieved from http://www.rockefellerfoundation. org/uploads/files/dc8aefda-bc49-4246-9e929026bc0eed04-africas turn.pdf

Shiva, V. (2014, March 13). The seeds of suicide: How Monsanto destroys farming. Global Research. Retrieved from http://www.globalresearch.ca/theseeds-of-suicide-how-monsanto-destroysfarming/5329947

Zurayk, R. (2014, May). The morning after: The Arab uprisings through an agrarian lens. Paper presented at the Middle East Institute Annual Conference 2014, National University of Singapore. Singapore. 